Pomáhajúce profesie, roč. 3, č. 2, 2020, 5-11

\title{
NÁZORY SESTIER NA VZDELÁVANIE V OŠETROVATELSTVE V SÚČASNÝCH PODMIENKACH NA SLOVENSKU
}

\author{
Andrea Botíková1, Marianna Hlavinková2, Ol'ga Kabátová1, Alena Dziacka ${ }^{1}$ \\ 1Katedra ošetrovatel'stva FZSP TU Trnava \\ 2 Interná klinika FN Trnava \\ andrea.botikova@truni.sk; olga.kabatova@truni.sk; alena.dziacka@truni.sk
}

\begin{abstract}
Abstrakt: Východiská: V posledných desat'ročiach dochádza k snahám harmonizovat' európske ošetrovatel'ské vzdelávanie, čo má zásadný vplyv i na vzdelávanie slovenských sestier.

Ciel': Ciel'om prieskumu bolo zmapovat' názory sestier na súčasné pregraduálne vzdelávanie v ošetrovatel'stve na Slovensku. Metódy: Kvantitatívny prieskum bol realizovaný prostredníctvom on-line dotazníka vlastnej konštrukcie. Výber súboru respondentov bol zámerný, kritériom zaradenia do prieskumnej vzorky bola registrácia v SKSaPA (Slovenská komora sestier a pôrodných asistentiek). Celkovú prieskumnú vzorku tvorilo 805 respondentov. Výsledky: Analýzou dát sme dospeli k záveru, že so súčasným systémom vzdelávania úplne súhlasí iba 12 \% sestier a až 58 $\%$ sestier je presvedčených, že vzdelávanie by sa malo vrátit’ na stredné školy. Implikácie: Odporúčame komplexne preskúmat' oblast' vzdelávania sestier s ciel'om identifikovat' problém, pre ktorý sú sestry v tejto oblasti nespokojné.
\end{abstract}

Klúčové slová: Ošetrovatel'stvo. Vzdelávanie. Názor. Postoj. Sestra. Súčasnost'.

\section{1 ÚVOD}

Za posledné desat'ročia sa v Európe zrealizovalo v ošetrovatel'skom vzdelávaní niekol'ko reforiem, najmä v rôznych procesoch, ktoré sa ho snažia harmonizovat'. Napriek týmto procesom systém ošetrovatel'ského vzdelávania stále nemá koherenciu (Spitzer, Perrenoud, 2006). V Európe mali zásadný vplyv na ošetrovatel'ské vzdelávanie smernice Európskej únie (EÚ) a Bolonská deklarácia prijatá v roku 1999. Bolonská deklarácia a jej následné procesy sú jednou z najdôležitejších reforiem vysokoškolského vzdelávania. Jej hlavným ciel’om bolo vytvorit’ súdržnejší, kompatibilný, porovnatel'ný a konkurencieschopný Európsky vysokoškolský priestor (Davies, 2008). Na dosiahnutie tohto ciel'a je potrebných šest' akčných línií a to prijatie systému l'ahko čitatel'ných a porovnatel'ných akademických hodností pre každú disciplínu, prijatie systému štúdia založeného v podstate na dvoch hlavných cykloch - pregraduálnom (bakalár) a postgraduálnom (magister, doktor), vytvorenie systému kreditov ECTS, prijatie dodatku k diplomu ako systému štandardizovaných informácií, podpora mobility študentov, pedagógov a podpora systému kvality vzdelávania (European Ministers of Education, 1999). V jednotlivých štátoch EÚ však stále existujú nezrovnalosti v teoretických aj klinických štúdiách a absentuje spoločné jadro učebných osnov vo vzdelávaní sestier. Realizácia týchto učebných osnov závisí od kultúr rôznych krajín, potrieb zdravotnej starostlivosti, filozofie zdravotnej starostlivosti, ekonomickej situácie, migrácie a prist'ahovalectva. Preto sa ošetrovatel'ské vzdelávanie rozvíja väčšinou podl'a politík rôznych krajín (Salminem et al., 2010). Na Slovensku bolo od 1. septembra 2001 zrušené úplné stredné odborné štúdium v odbore všeobecná sestra, ktoré končilo maturitnou skúškou, pretože nevyhovovalo kritériám smerníc EÚ (Farkašová et al., 2009). V súčasnosti sa vzdelávanie sestier riadi Smernicou 2013/55/EÚ. Ošetrovatel’skú starostlivost' poskytujú sestry, ktoré majú zákonom vymedzené kompetencie. Sú to osoby, ktoré získali profesijnú kvalifikáciu v študijných programoch 
na vysokých školách, ktoré boli akreditované v súlade so smernicami Európskej únie (Boroňová, 2018). Odborná spôsobilost' na výkon zdravotníckeho povolania, spôsobe d'alšieho vzdelávania zdravotníckych pracovníkov, sústave špecializačných odborov a certifikačných pracovných činností je zakotvená v Nariadení vlády SR č. 34/2018, Z. z. v znení neskorších predpisov. Kritériá a spôsob hodnotenia sústavného vzdelávania zdravotníckych pracovníkov stanovuje Vyhláška MZSR č. 74/2019 Z. z.. Súčasné vzdelávanie v ošetrovatel'stve na Slovensku spíňa európsky štandard a reflektuje potreby a požiadavky ošetrovatel'skej praxe.

Ciel’om prieskumu bolo zmapovat’ názory a postoje slovenských sestier na súčasné vzdelávanie v ošetrovatel'stve na Slovensku so zameraním na vnímanie rozdielnosti v kompetenciách sestier a praktických sestier (zdravotníckych asistentov).

\section{METÓDY}

Kvantitatívny prieskum bol realizovaný prostredníctvom dotazníka vlastnej konštrukcie, ktorý bol vol'ne dostupný na portáli Slovenskej komory sestier a pôrodných asistentiek (SKSaPA). Prieskum prebiehal v mesiacoch december 2018 až február 2019. Výber súboru respondentov bol zámerný. Kritérium zaradenia do prieskumnej vzorky bola registrácia v SKSaPA. Celkovú prieskumnú vzorku tvorilo 805 respondentov. Prieskumu sa zúčastnili sestry rôzneho veku, vzdelania a dížky odbornej praxe (Tabul'ka 1). Získané dáta sme vyhodnotili v programe MS Excel.

\begin{tabular}{|c|c|c|c|c|c|}
\hline $\begin{array}{c}\text { Vek } \\
\text { (v rokoch) }\end{array}$ & $\%$ & Vzdelanie & $\%$ & $\begin{array}{c}\text { Dížka praxe } \\
\text { (v rokoch) }\end{array}$ & $\%$ \\
\hline $21-29$ & 19 & stredoškolské & 20 & $1-5$ & 26 \\
\hline $30-44$ & 26 & vyššie odborné & 11 & $6-10$ & 12 \\
\hline $45-59$ & 35 & $\begin{array}{l}\text { vysokoškolské } \\
\text { I. stupňa }\end{array}$ & 32 & $11-20$ & 17 \\
\hline \multirow[t]{2}{*}{60 a viac } & 20 & $\begin{array}{l}\text { vysokoškolské } \\
\text { II. stupňa }\end{array}$ & 31 & $21-30$ & 26 \\
\hline & & iné & 6 & 31 a viac & 19 \\
\hline spolu & 100 & & 100 & & 100 \\
\hline
\end{tabular}

$\mathrm{n}=805$

\section{VÝSLEDKY A DISKUSIA}

V úvode sme zist'ovali, či sa sestry stotožňujú so súčasným systémom vzdelávania $\mathrm{v}$ ošetrovatel'stve a aký postoj k nemu majú. Zistili sme, že s vysokoškolským vzdelávaním úplne súhlasí iba 12 \% sestier a až 58 \% sestier si myslí, že štúdium ošetrovatel'stva by sa malo vrátit' na stredné školy. Odpovede sestier sú znázornené v tabul'ke 2. 
Tabul'ka 2 Názory sestier na vzdelávanie v ošetrovatel'stve

\begin{tabular}{cccccc}
\hline Názor sestier & $\begin{array}{c}\text { Úplne } \\
\text { súhlasím } \\
\text { \% }\end{array}$ & $\begin{array}{c}\text { Čiastočne } \\
\text { súhlasím } \\
\mathbf{\%}\end{array}$ & $\begin{array}{c}\text { Čiastočne } \\
\text { nesúhlasím } \\
\mathbf{\%}\end{array}$ & $\begin{array}{c}\text { Úplne } \\
\text { nesúhlasím } \\
\mathbf{\%}\end{array}$ & $\begin{array}{c}\text { Spolu } \\
\mathbf{\%}\end{array}$ \\
\hline $\begin{array}{c}\text { Stotožnenie } \\
\text { so súčasným } \\
\text { vzdelávaním }\end{array}$ & 12 & 34 & 28 & 26 & $\mathbf{1 0 0}$ \\
\hline $\begin{array}{c}\text { Návrat na } \\
\text { stredné školy }\end{array}$ & 58 & 16 & 13 & 13 & $\mathbf{1 0 0}$ \\
\hline $\mathrm{n}=805$ & & & &
\end{tabular}

D̆alej sme zist'ovali, aké benefity sestry vidia vo vyššom vzdelaní. Výsledky sú uvedené v tabul'ke 3. Za najväčší benefit vyššieho vzdelania považujú sestry vyššiu kvalitu starostlivosti (23 \%), väčšie kompetencie (15 \%), vyšší plat (15\%) a kariérny postup (15\%). Iba 7 \% sestier úplne súhlasilo s tvrdením, že čím vyššie vzdelanie, tým vyššie postavenie v spoločnosti.

Tabul'ka 3 Benefity vyššieho vzdelania

\begin{tabular}{cccccc}
\hline Benefity & $\begin{array}{c}\text { Úplne } \\
\text { súhlasím } \\
\%\end{array}$ & $\begin{array}{c}\text { Čiastočne } \\
\text { súhlasím } \\
\%\end{array}$ & $\begin{array}{c}\text { Čiastočne } \\
\text { nesúhlasím } \\
\%\end{array}$ & $\begin{array}{c}\text { Úplne } \\
\text { nesúhlasím } \\
\%\end{array}$ & $\begin{array}{c}\text { Spolu } \\
\%\end{array}$ \\
\hline Vyšší plat & 15 & 39 & 16 & 30 & $\mathbf{1 0 0}$ \\
\hline $\begin{array}{c}\text { Kariérny } \\
\text { postup }\end{array}$ & 15 & 52 & 17 & 16 & $\mathbf{1 0 0}$ \\
\hline $\begin{array}{c}\text { Vyššie } \\
\text { postavenie v } \\
\text { spoločnosti }\end{array}$ & 7 & 31 & 23 & 39 & $\mathbf{1 0 0}$ \\
\hline $\begin{array}{c}\text { Vyššie } \\
\text { kompetencie }\end{array}$ & 17 & 43 & 21 & 19 & $\mathbf{1 0 0}$ \\
\hline $\begin{array}{l}\text { Vyššia kvalita } \\
\text { starostlivosti }\end{array}$ & 23 & 26 & 26 & 25 & $\mathbf{1 0 0}$ \\
\hline $\mathrm{n}=805$ & & & &
\end{tabular}

Názory na vzdelávanie v ošetrovatel'stve mali možnost' sestry vyjadrit' percentuálne aj slovne. Percentuálne uviedlo pozitívny postoj k vzdelávaniu iba $35 \%$ sestier, $9 \%$ sestier sa nevyjadrilo a až $56 \%$ sestier uviedlo, že k súčasnému vzdelávaniu v ošetrovatel'stve má negatívny postoj. V nasledujúcej časti (Tabul'ka 4) uvádzame najčastejšie a najzaujímavejšie slovné odpovede sestier na súčasné ošetrovatel'ské vzdelávanie.

Tabul'ka $4 \quad$ Názory sestier na vzdelávanie v ošetrovatel'stve

\begin{tabular}{|c|c|}
\hline Pozitívne názory (35\%) & Negatívne názory (56\%) \\
\hline $\begin{array}{l}\text { "sestra by mala mat' minimálne Bc. vzdelanie a } \\
\text { kontinuálne sa vzdelávat' } s \text { podporou } \\
\text { zamestnávatel'a“ } \\
\text { „Je mimoriadne potrebné." }\end{array}$ & $\begin{array}{l}\text { „Pre prax je dôležitá špecializácia v odboroch, } \\
\text { vysokoškolské vzdelanie je dôležité pre výkon } \\
\text { funkcie." } \\
\text { „Je komplikované." }\end{array}$ \\
\hline
\end{tabular}


„sestra má mat’v dnešnej dobe vysokoškolské vzdelanie, minimálne Bc."

„sestry sa majú vzdelávat', vysokoškolsky vzdelané sestry majú viac vedomostí, ktoré využívajú v praxi“

„Je dôležité“ „VŽdy sa treba vzdelávat', mení sa zdravotníctvo, spôsoby liečby..."

„Príprava na získanie odbornej spôsobilosti pre výkon povolania sestra je dobré a v súlade s EU legislatívou"

„Sestry by mali mat vysokoškolské vzdelanie a mali by sa $v$ praxi venovat' odborným činnostiam. Ošetrovatel'skú starostlivost' by mali vykonávat' asistentky sestry so strednou školou, čo je rovnako dôležité povolanie a obe by mali byt' náležite ohodnotené."

„vzdelaná sestra = vyššia bezpečnost' pre pacienta"

„lepšia pripravenost' na povolanie" „kritické myslenie, väčšia samostatnost"
„Chcelo by to rozhodne viac praxe."

„Systém by sa mal mierne upravit', ale to si vyžaduje komplexné riešenie zo strany štátu, vzdelávacích inštitúcií a $v$ neposlednom rade aj zo strany sestier."

„treba vrátit' stredné zdravotnícke školy"

„Sestry sa vzdelávajú, majú dostatok kvalitných vedomostí ale $v$ spoločnosti aj tak nič neznamenajú pre pacientov sú to len obyčajné slúžky"

„Nemá sa kto postarat' o pacientov lebo vysokoškolský vzdelané sestry nebudú „prebal'ovat" pacientov a to je vel'ký problém $v$ dnešnej dobe len sa sedí a t'uká do počítača a píše na papiere a pacient je niekde na samom konci."

„Ponechala by som SZŠ ale s takou náplňou štúdia ako bola pred 20 rokmi resp. aby bola naplnená legislatíva, môže byt' 5 ročné a sestry by získali titul diplomovaná sestra. V súčasnosti sa málo hodín venuje pediatrickému ošetrovatel'stvu či už v teoretickej výučbe ako aj praktickej."

„Zbytočné, postačuje to čo sa vyučovalo na SZŠ.“ „,nedomyslené...nezohl'adňuje potreby praxe“

Väčšina európskych krajín podporuje akademizáciu ošetrovatel’stva, ktorá zahŕňa prevod vzdelávania sestier na univerzity alebo na iné vysokoškolské inštitúcie. Tento proces je však v mnohých európskych štátoch $\mathrm{v}$ rôznych štádiách a to najmä kvôli historickým vplyvom a politickým tlakom (Jackson et al., 2009). Slovenské zdravotnícke školstvo sa snaží zabezpečit' vysokú pripravenost' zdravotníckych pracovníkov, teda aj sestier. Na to, aby dokázali zvládnut' náročné situácie, musia mat’ na vysokej úrovni profesionalitu, morálne presvedčenie a empatiu. Sestry musia byt' pohotové a mat’ individuálny a tvorivý prístup k jednotlivcom a skupinám. Všetky zmeny vo vzdelávaní sestier, ktoré počas minulosti nastali, viedli k súčasnému ciel'u zabezpečit' čo najvyšší stupeň rozvoja odborných vedomostí, zručností a osobnostných schopností, vrátane plného uvedomenia si potreby d'alšieho vzdelávania sestier, s ciel’om zabezpečit' kvalitnú a odbornú zdravotnú a ošetrovatel'skú starostlivost' (MZSR, 2011). Hoci od zavedenia súčasného spôsobu vzdelávania ubehlo už 18 rokov, stále sa stretáva s nepochopením a negatívnym postojom nielen z radov laikov, ale i samotných sestier. Celosvetový dopyt po vysokoškolskom vzdelávaní je spôsobený zvyšujúcimi sa potrebami trhu práce pre vysokokvalifikovaných pracovníkov, ako sú i sestry (Baumann, Blythe, 2008). V našom prieskume sme zistili, že iba $12 \%$ sestier sa úplne stotožňuje so súčasným vzdelávaním v ošetrovatel'stve a až 58 \% z nich úplne súhlasí s názorom, že vzdelávanie sestier by sa malo vrátit’ na stredné zdravotnícke školy. Čakloš (2017) zist'oval, aký názor majú sestry na pregraduálne vzdelávanie. Sestry, ktoré absolvovali vysokoškolské štúdium, boli toho názoru, že po absolvovaní vysokej školy sú viac vyspelé a pristupujú k vzdelávaniu 
zodpovednejšie. Tie sestry, ktoré s vysokoškolským vzdelávaním nesúhlasili, naopak tvrdili, že v minulosti stredoškolské vzdelanie postačovalo. Massimi et al. (2017) zistili, že sestry, ktoré absolvovali vysokoškolské štúdium, hodnotili získané vedomosti a zručnosti, ako užitočné pre ich profesionálny život. Sú expertmi vo svojom odbore, získali profesionálny rast a štúdium celkovo hodnotia ako vel'mi dobré alebo excelentné. Štúdia, ktorú vykonali Watkins et al. (2011) odhalila, že absolvovanie vysokoškolského štúdia sestrám zvýšilo osobnostnú aj profesionálnu sebadôveru, vyskytli sa nové roly v povolaní sestier, rozšírila sa multidisciplinárna spolupráca a sestry znovuobjavili ošetrovatel'stvo. V našom prieskume sme zistili, že respondenti považujú za najväčší benefit vyššieho vzdelania vyššiu kvalitu starostlivosti, vyššie kompetencie, vyšší plat a kariérny postup. Vzdelávanie je pre sestry neoddelitel'nou súčast'ou profesie pre poskytovanie čo najodbornejšej a najbezpečnejšej ošetrovatel'skej starostlivosti. To, že vyššie vzdelanie je priamo úmerné kvalite poskytovanej starostlivosti dokazujú mnohé zahraničné výskumy. Audet et al. (2018) zistili, že vyšší stupeň vzdelania u sestier je spojený s nižším výskytom rizík zo zlyhania. Ball et al (2018) vo svojej štúdii zistili, že najčastejšou príčinou pochybenia v ošetrovatel'skej starostlivosti je nedostatok času na pacientov, kedy sestra nestíha dokončit' všetku nevyhnutnú ošetrovatel'skú starostlivost'. Štúdia taktiež potvrdila, že ošetrovatel'ská starostlivost' poskytovaná sestrami s vyšším vzdelaním je spojená s nižšou pooperačnou úmrtnost'ou. Vzdelanie sestier je priamo úmerné ich kompetenciám. Kompetencie sestier sú na Slovensku odstupňované podl'a vzdelania a dížky praxe. Sestry sú rozdelené do štyroch kategórií - registrovaná sestra, sestra so špecializáciou, sestra s pokročilou praxou a sestra pre riadenie ošetrovatel'skej praxe.

Registrovaná sestra je sestra, ktorá nadobudla odbornú spôsobilost' v bakalárskom študijnom programe. Sestra špecialistka je sestra, ktorá získala odbornú spôsobilost' na výkon špecializovaných pracovných činností. Sestra s pokročilou praxou je sestra, ktorá získala odbornú spôsobilost' $\mathrm{v}$ bakalárskom aj magisterskom študijnom programe v študijnom odbore ošetrovatel'stvo a špecializáciu v príslušnom špecializačnom obore, a ktorá následne získala pät' ročnú odbornú prax v príslušnom špecializačnom odbore. Sestrou s pokročilou praxou je taktiež sestra, ktorá získala vysokoškolské vzdelanie $\mathrm{v}$ bakalárskom aj $\mathrm{v}$ magisterskom študijnom programe v študijnom odbore ošetrovatel'stvo a nadobudla najmenej osemročnú odbornú prax. Sestra pre riadenie ošetrovatel'skej praxe je sestra, ktorá dosiahla rovnaké vzdelanie a prax ako je uvedené vyššie pri sestre s pokročilou praxou (Böszörményiová, 2018).

Naopak najmenej sestier v našom prieskume úplne súhlasilo $s$ tvrdením, že čím vyššie vzdelanie, tým vyššie postavenie v spoločnosti sestra má. Profesia sestry patrí medzi pomáhajúce profesie, ktoré si vyžadujú celého človeka, a tie aj napriek vel'kej psychickej a fyzickej náročnosti zrejme nikdy nebudú spoločensky ani finančne dostatočne docenené aj napriek tomu, že ide o jedinečné a nenahraditel'né povolanie pri poskytovaní ošetrovatel'skej starostlivosti (Ištoňová et al., 2010).

\section{ZÁVER}

Vzdelávanie je neoddelitel'nou súčast'ou praxe každej sestry pri poskytovaní odbornej a kvalifikovanej ošetrovatel'skej starostlivosti. Je prevenciou vzniku pochybenia, neprofesionálnej starostlivosti a poškodenia pacienta. Na základe dát, ktoré sme získali v našom prieskume môžeme zhodnotit', že rozpoltenost' názorov samotných sestier na vzdelávanie v ošetrovatel'stve je skutočne nesmierna. $V$ rámci pregraduálneho vzdelávania je potrebné rozvíjat' a podporovat' výskum v oblasti vzdelávania sestier, orientovat' sa na identifikovanie problému, pre ktorý nie sú sestry stotožnené so súčasným spôsobom vzdelávania. Tiež odporúčame zvýšit’ informovanost' sestier, ale i laickej verejnosti o dôležitosti vyššieho vzdelania $\mathrm{v}$ ošetrovatel'stve $\mathrm{z}$ dôvodu profesionálneho rastu a zlepšenia multidisciplinárnej spolupráce. Účelom tohto rukopisu je zdôraznit' nevyhnutnost' spoločných vzdelávacích štandardov pre regulované povolanie sestra. $\mathrm{V}$ súvislosti so vzdelávaním sestier na celoeurópskej úrovni by bolo vhodné vytvorit' a aplikovat' medzinárodný vzdelávací program pre sestry jednotný a platný vo všetkých krajinách EÚ. 


\section{LITERATÚRA}

Audet, L. et al. (2018). Association between nurse education and experience and the risk of mortality and adverse events in acute care hospitals: A systematic review of observational studies. Nurse Education Today, 80(4), 128-146.

Ball, J. E. et al. (2018). Post-operative mortality, missed care and nurse staffing in nine countries: A cross-sectional study. Nurse Education Today, 78(4), 10-15.

Baumann, A., Blythe, J. (2008). Globalization of Higher Education in Nursing. The Online Journal of Issues in Nursing, 13(2), 4.

Boroňová, J. (2018). Vybrané témy z ošetrovatel'skej problematiky. Trnava: Typi Universitatis Tyrnaviensis. $320 \mathrm{~s}$.

Böszörményiová, J. (2018). Sestry, máte viac kompetencií. MediPRÁVNIK [online].[cit. 2019-0502]. Dostupné z:

https://www.medipravnik.sk/clanky/sestry-mate-viac-kompetencii-313/.

Čakloš, M. (2017). Názory sestier na pregraduálne vzdelávanie v profesii sestra. Slovenská komora sestier a pôrodných asistentiek [online]. [cit. 2019-02-17]. Dostupné z: https://www.sksapa.sk/monitoring-medii/sestra-nazory-sestier-na-pregradualne-vzdelavaniev-profesii.html.

Davies, R. (2008). The Bologna process: The quite revolution in higher education. Nurse Education Today, 28(4), 935-942.

European Ministers of Education (1999). Bologna Declaration. [online]. [cit. 2019-03-11]. Dostupné z: http//eceuropa.eu/education/policies/educ/bologna/bologna.pdf.

Farkašová, D. a kol. (2009). Ošetrovatel'stvo - teória. 3. vyd. Martin:Osveta, 2009. 245 s.

Ištoňová, M., Palát, M., Čechov-Špirková, A. (2010). Ergonomické princípy v pracovnej činnosti sestry. Dolista, J. (ed.) Práce pomáhajících profesí v oblasti zdravotnictva a sociální péče. Praha: Evropské vzdělávací centrum, 2010. s. 137- 149.

Jackson, C. et al. (2009): A review of nurse educator career pathways; a European perspective. Journal of Research in Nursing, 14(2), 111-122.

Massimi, A. et al. (2017). Quality and relevance of master degree education for the professional development of nurses and midwives. Nurse Education Today. 53(3), 54-60.

Ministerstvo zdravotníctva Slovenskej Republiky (2011). Príprava na výkon povolania. [online]. [cit. 2018-09-29] Dostupné z: http://www.health.gov.sk/?priprava-na-vykon-povolania-1

Salminem, L. et al. (2010). Future challenges for nursing education - A European perspective. Nurse Education Today, 30(3), 233-238.

Spitzer, A., Perrenoud, B. (2006). Reforms in nursing education across Western Europe: from agenda to practice. Journal of Professional Nursing, 22(3), 150-161.

Watkins, D. (2011). The influence of Master education on the professional lives of British and German nurses and the further professionalization of nursing. JAN Leading Global Nursing Research. 67(12), 2605-2614. 


\title{
NURSES‘ OPINIONS ABOUT NURSING EDUCATION IN CURRENT CONDITIONS IN SLOVAKIA
}

\begin{abstract}
Background: In recent decades, efforts have been made to harmonize European nursing education, which has essentially impacted the education of Slovak nurses. Objective: The aim of the survey was to map nurses' opinions about current pregraduate nursing education in Slovakia. Methods: The quantitative survey was carried out through an online questionnaire of our own design. The respondents had to be registered in SKSaPA (Slovak Chamber of Nurses and Midwives). The total survey sample consisted of 805 respondents. Results: Only $12 \%$ of nurses fully agree with the current education system and $58 \%$ of nurses believe that nurses should be trained at vocational schools. Implications: We recommend a comprehensive assessment of nursing education in order to identify the primary source of nurses dissatisfaction with current nursing education.
\end{abstract}

Key words: Nursing. Education. Opinion. Nurse. Present. 